\title{
International Money and Common Currencies in Historical Perspective
}

Gerald P. Dwyer Jr.

Federal Reserve Bank of Atlanta

James R. Lothian

Fordham University

Follow this and additional works at: https://fordham.bepress.com/crif_working_papers

Part of the Finance and Financial Management Commons

\section{Recommended Citation}

Dwyer Jr., Gerald P. and Lothian, James R., "International Money and Common Currencies in Historical Perspective" (2002). CRIF Working Paper series. 14.

https://fordham.bepress.com/crif_working_papers/14 


\title{
International Money and Common Currencies in Historical Perspective
}

\author{
Gerald P. Dwyer Jr.* \\ Federal Reserve Bank of Atlanta \\ James R. Lothian \\ Fordham University
}

May 2002

\begin{abstract}
We review the history of international monies and the theory related to their adoption and use. There are four key characteristics of these currencies: high unitary value; relatively low inflation rates for long periods; issuance by major economic and trading powers; and spontaneous, as opposed to planned, adoption internationally. The economic theory of the demand for money provides support for the importance of these characteristics. The value of a unit is arbitrary for a fiat money, but the other characteristics are likely to be important for determining any fiat money that will be the international money in the future. If the euro continues to exist for the next half century or so and has a relatively stable value, we conclude that the euro is likely to be serious competition for the dollar as the international money.

JEL codes: E42, F33, N10

* Vice President, Research Department, Federal Reserve Bank of Atlanta, 1000 Peachtree Street N.E., Atlanta, Georgia 30309, USA, tel. 1404 498-7095, email: Gerald.P.Dwyer@atl.frb.org; and Distinguished Professor of Finance, Schools of Business, Fordham University, 113 West $60^{\text {th }}$ Street, New York, NY 10023, USA, tel.: 1212636 6147; email: lothian@fordham.edu. We presented an earlier version of this paper at the Conference on Euro and Dollarization: Forms of Monetary Union in Integrating Regions. We thank Sven Arndt, Benjamin J. Cohen, Cesare Robotti and George von Furstenberg for comments on an earlier draft of this paper. The views expressed here are the authors' and not necessarily those of the Federal Reserve Bank of Atlanta or the Federal Reserve System.
\end{abstract}




\section{Introduction}

Is the euro likely to supplant the dollar as an international money? Such a question might seem premature, especially since the euro physically has been in existence only for a few months. We are inclined to think that it is not too early to start to think about this issue seriously since the implications are large for the world's monetary landscape.

The move to a circulating euro on January 1,2002 has been followed by little or no difficulty in the twelve countries involved. By most prognostications, moreover, the future for the new currency looks very good. That was not the case at all a decade ago, as devaluations and widened currency bands shook the Exchange Rate Mechanism (ERM). Skepticism with regard to the future of a single currency abounded among both economists and financial professionals.

A major reason for this shift in opinion has doubtless been the change in the underlying economic environment in the countries involved, in particular the greater convergence in monetary policies that took place during the intervening period.

The purpose of this paper is to review the historical evidence on the question of international monies. In contrast to other studies, we adopt a very broad temporal perspective, beginning with a discussion of the Byzantine gold solidus or bezant that was introduced by the Emperor Constantine and that served as a world currency for the next seven centuries. We continue with a review of medieval monetary history and the international currencies of the Italian city states. ${ }^{1}$ We then turn to a discussion of the various international monies that have existed from the early modern period to the present.

\footnotetext{
${ }^{1}$ On these issues see Cipolla (1967) and Lothian (2002 forthcoming).
} 
Using this review of the historical evidence as a background, we go on to discuss the theory surrounding this issue. The underlying questions of interest are with the factors affecting the establishment of common currencies and, more important, their longevity. Here we return to the earlier analyses of Carl Menger (1892) and a century later Friedrich A. Hayek (1978). In both analyses, the key distinction using some terminology borrowed from Hayek (1967) is between monetary institutions that are the result of human action but not human design and institutions that are planned and orchestrated from on high.

\section{Historical Overview}

\subsection{The Early Middle Ages}

International monies, monies that circulate for usein transactions across national boundaries, begin with the silver drachma first coined in ancient Athens in the fifth century B.C. (Chown, 1994). Judged on the basis of the hoards that have been uncovered, not just within the Mediterranean region but throughout Europe and well into Asia, the coinage of Rome - first the gold aureus and the silver denarius after the currency reforms of Augustus - became the drachma's successor. ${ }^{2}$ Beginning with Nero (A.D. 54-68) and continuing into the early fourth century, currency debasement and inflation became the rule. An unsurprising effect of this continual depreciation was a decline in the acceptability of the Roman coinage outside the narrower confines of the Roman empire. The denarius, which had its specie content reduced entirely, ceased to function as money internationally. The aureus kept its fineness in terms of specie but was issued as a lighter coin and became more commodity than money, being valued by weight rather than by its face value.

2 This discussion of Roman currency draws on Einzig's (1962) monograph on exchangerate history. As Cohen (1998) points out, there was a substantial overlap period after Rome's ascendancy in which the silver drachma continued to circulate along with the Roman coinage. 
After earlier attempts at reform failed, the Emperor Constantine introduced a new currency, the solidus. Called the nomisma by the Greeks and the bezant by Western Europeans, the solidus continued to be minted in Byzantium until that city fell to the crusaders in 1203, and for a while thereafter was still minted in Nicea, the new seat of the then much diminished Byzantine Empire.

The solidus was a relatively heavy, full-bodied gold coin meant for use in large transactions. It soon became an international currency. The Greek monk Cosmas Indicopleustes, a contemporary observer - writing during the reign of the Emperor Justinian I (A.D. 527-565) - reports that the solidus was "accepted everywhere from end to end of the earth." ${ }^{3}$ He goes on to say that it is "admired by all men and in all kingdoms, because no kingdom has a currency that can be compared to it." The economic historian and medievalist R.S. Lopez (1951) in reviewing the solidus' history uses the term "Dollar of the Middle Ages" to describe it. Based on the hoards of coins that subsequent research has uncovered, he traces its sphere of influence from England to India, an area in which he claims (p. 211) it was accepted "as an instrument of payment as good as gold itself."

The solidus contained the equivalent of 4.5 grams of pure gold. The British gold sovereign and the ten-dollar gold U.S. Eagle by way of comparison contained roughly 8.0 and 8.8 grams, respectively. Valued at current market prices the gold in the solidus would be worth roughly $\$ 42$ and the gold in the eagle and the sovereign $\$ 73$ and $\$ 68$ respectively. Numismatic evidence suggests, moreover, that the solidus' gold content varied little from the fourth century through the mid-tenth century.

${ }^{3}$ The phrase "dollar of the middle ages" is that of R.S. Lopez (1951). Both Lopez (1951, p. 209) and Cipolla (1967, p. 15-16) cite the statement by Indicopleustes. Cipolla goes on to discuss corroborative evidence reported by earlier historians of the subject. 
The result was an international money with an historically unparalleled life span. The solidus did not, however, enjoy a monopoly over this full period. From the end of the seventh century, it shared its position with the dinar, an almost identical coin minted in various parts of the Moslem world. Introduced in the last decade of the seventh century by Abd el Malek, the fifth caliph (A.D. 685-705) of the Syrian Umayyad dynasty, the dinar like the solidus kept a stable metallic content for centuries.

The fall from grace of the solidus and the dinar began at roughly the same time and for very much the same reasons. Fiscal strains led to increased money creation which for commodity monies means debasement in one or both of two forms: 1. a decrease in the weight of the coins: 2. an alteration of their relative specie content, their fineness. From the standpoint of the usefulness of the currency in trade and hence confidence in it, the first is the less harmful of the two. Coins can be valued by weight. Even without debasement, coins often become worn through use and were weighed to determine their value.

For the solidus, debasement by reducing the weight started in the late tenth century under the Emperors Nicephorus Phocas (963-969) and John Tzimiskes (969-976) and continued into the eleventh cent ury. As so often has been the case, financing high levels of government expenditures was the impetus for debasing the money. ${ }^{4}$ The death knell for the solidus' status as an international currency was sounded in the late eleventh century when the fineness was reduced. Nevertheless, a solidus of close to the old weight was still minted (along with inferior coins) in the early thirteenth

${ }^{4}$ Sussman (1993) presents a sound analysis of later debasements which illustrates the general principles and raises the right questions. Rolnick et al. (1996) present some stylized observations about debasements and Velde et al. (1999) present a simple analysis that highlights the general asymmetric information that can rationalize the profitability of debasements. 
century in Nicea following the fall of Constantinople to the Crusaders in 1203. Debasement of the dinar also began in the late tenth century. The explanation again appears to be largely fiscal.

\subsection{The Thirteenth Century Commercial Revolution and the European Return to Gold}

Although the reach of the solidus extended well into Northern Europe, it was used most extensively in the Mediterranean region. Northern Europe as well as Western Europe had no counterpart to the solidus and was otherwise less of a money economy than either the Byzantine Empire or the Moslem nations.

That situation changed in the thirteenth century. The thirteenth century was extraordinary in a number of ways. It was a time of great learning and considerable scholarly interchange by all accounts. ${ }^{5}$ It was the start of a European commercial revolution, the chief manifestation of which was substantially increased trade not only within Europe itself but between Europe and the rest of the world. It also was a time of considerable financial innovation including the return to gold coinage in Western Europe.

International trade was centered around the fairs that were held regularly throughout Europe, the fairs of Champagne being the most important. These fairs also were foreign-exchange centers. Initially the money changers at the fairs, who also were merchants and gave rise to the term "merchant banker", confined their activities to manual exchange, the changing of one type of coin for another. Then as bills of exchange increasingly came into use, the money changers increased their roles and became intermediaries in this market.

5 See Spufford (1984) on the commercial revolution and the financial developments that accompanied it. On broader cultural issues - philosophical and economic thought and university life - see Gilson (1991) and Schumpeter (1954). 
The reintroduction of a Western European gold coinage took place in 1252 with the striking of two full-bodied gold coins in Northern Italy - the genoin of Genoa and then a few months later the fiorino (or florin) of Florence. These two coins, but particularly the florin, were the world currencies. In the fifteenth century, however, their place was taken by the ducato of Venice. All three coins circulated side by side with coins of two other sorts - token coins used in small transactions and silver coins used in somewhat larger transactions.

Gresham's Law did not come into play for any of these three coins because exchange rates among the various coinages remained flexible. The data that exist for this period suggest that there was a surprisingly active market in foreign exchange. Exchange-rate data, in fact, indicate why the two coins, the florin and the genoin, were attractive and became international currencies. We can see this in Table 10.1 which lists exchange rates relative to the florin at fifty-year intervals for a variety of currencies.

What stands out is the depreciation of all currencies relative to the florin, shown by the upward trend in the exchange rates. A major cause of these movements was the series of debasements that took place in all of the European countries throughout this era. A second influence was the discovery and subsequent mining of silver in several European countries during the fifteenth century. These data are not consistent with the modern notion that a metallic money necessarily is a stable money.

A second point to notice in Table 10.1 is the difference in the pace at which the exchange-rate depreciation occurred. The English pound sterling, for example, showed relatively littlemovement, a drop in value of 0.2 per cent per year over these two and a half centuries. The Castilian marivedi, 
in contrast, registered a decline of 2.0 per cent per year over the 200 years for which data on it are available.

The debasement of these currencies does not seem to have been matched by increases in the various countries' price levels. The likely reason is that increases in money supplies were themselves matched at least to some degree by increases in real output and in desired quantities of money demanded.

These currencies, therefore, also served as units of account for bills of exchange, credit instruments which began in the thirteenth century to evolve into the principal form of international settlement. ${ }^{6}$ The primary purpose of these bills of exchange was to eliminate shipment of specie when goods were bought and sold. The mechanism was simple and evidently also quite effective, since the bill of exchange remained the major instrument used in foreign transactions until the end of the nineteenth century. Discountable bills still survive in modified form today, with payment now commonly being ensured by letters of credit.

A standard scenario involving the use of bills of exchange was something of the following sort: An English merchant wants to buy cloth from an Italian exporter. To pay for this transaction and to avoid having to ship specie, the English merchant purchases a bill of exchange from a London merchant banker. The bill of exchange is then sent as payment to the Italian exporter who ships the cloth and remits the bill to a merchant banker in Florence. The Florentine banker in turn pays the Italian exporter inflorins and then settles with the London banker. This settlement could be simply

${ }^{6}$ De Roover (1974, pp. 210-212) trace the development of bills of exchange to the letters of exchange and cambium contracts used a century or so before. See McCusker (1978, pp. 1923) and Neal (1990, pp. 6-9) for discussions of the mechanics of the transaction involved in the use of bills of exchange, and Einzig (1962) for a broader historical treatment. 
a bookkeeping transaction, the Florentine banker canceling offsetting obligations to the London banker, or settlement could involve a shipment of specie at some future time at which the two have agreed to reconcile their books. The use of bills of exchange became increasingly widespread from the thirteenth century on.

\subsection{Common Characteristics of Early International Monies}

Cipolla (1967) reviews monetary developments in both the early and later medieval period and points to three common characteristics of the various international monies. The first is high unitary value. We have already discussed this in connection with the solidus. It was also true of the dinar and the three Italian coins. The dinar contained approximately 4.25 grams and the three Italian coins contained approximately 3.5 grams of gold. Valuing these at today's price of gold of roughly $\$ 290$ per troy ounce, this works out to prices of roughly $\$ 40$ and $\$ 32$ respectively. In the United States today by way of comparison, most cash transactions are still carried out using twenty-dollar bills.

The second characteristic that the medieval monies shared during their respective hey-days was intrinsic stability. They all kept the same weight and fineness during these periods though their values in terms of goods and services did change over time. Correspondingly, in each instance after debasement set in, the currency eventually ceased to serve as an international money.

The third characteristic is that the various currencies were all issued by strong economic powers that were active in international trade. Since we will go on to consider international monies in today's context of fiat monies, it is useful to consider how well these characteristics apply to fiat monies. 
Intrinsic stability, the second of these requisite characteristics, would seem to be the most relevant for the success of fiat monies as well as metallic monies. In current terminology, it provided a nominal anchor. It applies with at least equal force to fiat monies as to commodity monies since the real value of fiat money can be easily affected by the issuer, something not as directly manipulable by issuers of commodity monies.

A large economy with a substantial presence in world trade, the third observed characteristic, is somewhat harder to pin down. Recently developed search-theoretic models of money, which we review below, suggest however that such scale effects do indeed matter. An alternative view is that a strong trade-oriented economy is simply an indicator of brand-name capital. Like sterling during the period in which Britain was the world's major power and the dollar today, such currencies could be viewed as subject to less risk of political upheaval. In either case, this generalization again applies with equal or greater force to fiat monies.

High unitary value, the first characteristic, is another matter entirely. The value of a unit of money is certainly not much of a restriction on fiat monies, because fiat monies weigh relatively little and it is cheap to change the units to whatever value makes them useful in international transactions. Cipolla, however, suggests that it might in fact be a mark of prestige. Lopez (1951) in his discussion of early medieval monies makes a similar observation. He says (p. 214-215):

Clearly, then, the bezant was more than a lump of gold. It was a symbol and a faith, the messenger of the divine emperor to his people and the ambassador of the chosen people to the other nations of the world. We cannot make fair appraisal of the monetary policies of the empire in strict economicterms since moral and psychological values also were involved and since these values by affecting the internal stability and international prestige of the state had, in their turn, a bearing on economic conditions. 
It is perhaps more obvious now than when Cipolla wrote that there is a fourth characteristic of these various world currencies: All of them were simply adopted. None of these international monies arose due to anyone's intention to create a new international money. Rather, their roles as international monies evolved due to their becoming generally acceptable to others over time. They thus achieved their status without any laws being passed, without any official monetary conferences being held, and without any foreign ministers issuing joint communiques. They became world monies, to use Hayek's (1967) terminology in his article of that name, as "the result of human action and not of human design.”

\section{International Monies from the Seventeenth Century to the Present}

International monies have continued to be used in more recent times.

\subsection{Later International Monies}

As the sixteenth century wore on, the center of international trade shifted from the Mediterranean region and the Italian city states to the northwest corner of Europe, first to Antwerp and then rather abruptly near the close of the sixteenth century to the Dutch Republic. In the century that followed, the Dutch economy experienced rapid growth. The United Provinces as a result became the world leader in shipping and in trade as well as in international finance. The Dutch currency also became the key currency in international transfers. It remained so, moreover, for most of the seventeenth and eighteenth centuries (see Dehing and 't Hart, 1997). Its strong suit, in addition to the preeminent Dutch economic and financial position, was its intrinsic stability.

The rise of the guilder was an evolutionary process. At the end of the sixteenth century, close to 800 different foreign coins were accepted in the Dutch Republic as money, and by 1810 the number had increased to nearly 1,000 (Dehing and ' $t$ Hart, 1997). Out of this bewildering array, the 
guilder emerged as the unit of account and the primary transactions currency. These two functions were, however, split between two versions of the currency. The guilder banco, the deposit entries on the books of the Bank of Amsterdam, became the unit of account. The circulating silver guilder was the medium of exchange. The two guilders - banco and coin - were closely but not rigidly linked. In 1638 the Amsterdam magistrates set a par value for the bank money in terms of the circulating medium, with the guilder banco at a slight premium. This premium, the agio, remained generally small and quite stable. From 1638 to 1775 , the agio was 4.1 per cent, implying an average internal rate of exchange between the two of 104.1 in guilder coinage per 100 guilder banco. The standard deviation of the agio over this period was only 1.1 per cent. ${ }^{7}$ The debasements that had been characteristic of the guilder until roughly 1630 was a thing of the past. As John McCusker (1978, p. 42) summarizes the situation, "The unchanging metallic content ... during the seventeenth and eighteenth centuries made Dutch money - with sterling - one of the soundest, moststable currencies in the world."

During the course of the seventeenth century, Dutch economic growth slowed appreciably and English growth began to accelerate (Israel, 1995). Near the end of that century, England started to develop into a financial power. The initial event here was the chartering of the Bank of England in 1694. Rapid development of English commercial banking followed. In the latter half of the eighteenth century, the number of London banks increased close to threefold and the number of banks outside London - the country banks - grew even faster, from a dozen or so in 1750 to 334 in 1797 to double that number in 1810 (Ashton, 1955, pp. 179-183). During this period, the London Stock Exchange also was formed and an active market in foreign exchange developed.

\footnotetext{
${ }^{7}$ These data are taken from McCusker (1978, Table 2.6, pp.46-51).
} 
By the last quarter of the eighteenth century England had replaced the Dutch Republic as the world's leading trading nation and London had replaced Amsterdam as its chief financial center (Jonker, 1997). Throughout, sterling remained a relatively stable currency and, although this stability was temporarily interrupted in the decade or two surrounding the Napoleonic Wars, it was reestablished soon afterwards and maintained until the start of the First World War. Sterling as a result, beca me the new international currency, benefitting not only from its inherent stability but also, and we think more importantly, from the new British primacy in international trade and finance. ${ }^{8}$

The United States became the world's largest economy in the late nineteenth century, with U.S. real Gross Domestic Product (GDP) surpassing U.K. real GDP in the last third of that cent ury. British financial and monetary dominance, however, continued until the start of the First World War. The outbreak of war was associated with substantial gold flows to the United States from Europe including the United Kingdom. New York, which had already become a major financial center, benefitted and London lost. After the Armistice in November of 1918, the world tried to get back to normal. Many of the belligerent countries returned to gold in the early 1920s. The United Kingdom only did so in 1925, after first experiencing half a decade of wrenching deflation. Sterling retained some of its status as an international money and reserve currency for a time but the position of the U.S. dollar in both regards strengthened. Then the Great Depression and World War II intervened and financial and trade links between countries, as much else, were disrupted.

The U.S. dollar was designated the official reserve currency of the fixed-exchange-rate system designed at the Bretton Woods Conference in 1944. After the war ended, the dollar not only

\footnotetext{
${ }^{8}$ See Benjamin J. Cohen (1998, p.31-32) for a discussion of the links between Britain's increasing importance in international finance after 1815 and the rise of sterling as an international currency.
} 
took on this role but became a widely used international money as well as a currency used in domestic transactions in various countries. A good idea of what went on during this period and its resemblance to times past is indicated by Cipolla's discussion $(1967, \mathrm{p} .13)$ in his monograph on medieval monies in which he, like Lopez (1951), compares the solidus to the dollar.

These pieces of paper [i.e. dollars], I knew, were more generally acceptable than any European currency. In any part of Europe there could be no difficulty in finding people who would take them as money . I could spend them everywhere, asking for everything. They were, they are, the international currency par excellence.

Fixed exchange rates among the world's currencies broke down in 1971 under the pressures unleashed by inflationary U.S. monetary policy (Darby, Lothian, et al., 1982: Bordo, 1993). Many believed at the time that the subsequent move to floating ex change rates would reduce the dollar's role. This was wrong on several counts. Official holdings of dollars as reserve assets remained high and greatly increased. Private demands for dollars increased, particularly once the United States got inflation under control and as other countries' inflation worsened. One indication of the extensiveness of this phenomenon is provided by the considerable number of papers in this volume that discuss dollarization.

\subsection{Further Empirical Generalizations}

This later experience is consistent with earlier experience: stability of value as well as country size and prominence in trade clearly matter. What appears important also, however, is financial development. All three of the later international currencies - the guilder, sterling and the dollar - were issued by countries with dominant positions in international finance and relatively unfettered markets. Cohen $(1971,1998)$ discusses this last characteristic under the headings of “exchange convenience" and "capital certainty." George S. Tavlas (1998) makes a similar point. He 
states that: "the issuing country should possess financial markets that are substantially free of controls, broad (that is, containing a wide variety of financial instruments), and deep (that is, having well-developed secondary markets)." Tavlas also argues that the issuing countrymust be politically stable and militarily powerful. This was certainly true of the three countries issuing these later international monies. It was also the case for the issuers of the earlier monies.

\section{Theoretical Considerations}

On one level, it is trivial to say that international fiat monies have arisen due to their being generally acceptable. A domestic fiat money arises due to its being generally acceptable in transactions and for no other reason. Why should an international fiat money be any different? Possibly the level of indeterminacy is more obvious for international fiat money. Perhaps it seems obvious that Argentine people would prefer to use the Argentine government's fiat money if other things are the same. It is much less obvious whether an Argentine will pick American, Brazilian, British or Swiss money when using non-Argentine money.

If legal restrictions are ignored, there is no particular reason to expect people in Argentina to bear substantial costs to use money issued by the Argentine government rather than by some other government. While people may be willing to bear some costs to use domestically produced money due to national pride or other nonpecuniary considerations, there is no reason to think that they will bear substantial costs. Programs to encourage people to buy domestically seldom, if ever, succeed. People buy the clothing that has the highest value to them personally, even if it is produced by foreigners. There is an important difference, though, between money and other domestic goods such as clothes. 
The money that is useful depends on what money is used by others, whereas a pair of shoes will be equally useful whether everyone else wears domestic or foreign shoes. This implies that there is a coordination problem that must be solved for choosing money, a problem that is largely irrelevant for clothes. It would be easy, though, to overemphasize the greater importance of coordination for money compared to other goods. Driving a foreign car is more useful if some other people drive one too because repair facilities will be nonexistent otherwise. The producer of the good, whether a car or a money, has an incentive to assist users.

The choice of a fiat money is a radical indeterminacy. Why did people in the United States in the 1790s use United States dollars rather than pounds sterling or French francs? It might seem that legal-tender laws resolve the question to some extent. Legal tender laws require that a money be acceptable inpayment. Everything else the same, if one money is legal tender and the other is not, the one that is legal tender seems likely to be the money used. This observation has not, however, been demonstrated in a well-articulated theory. In any case, alternative monies rarely are perfect substitutes.

\subsection{More Stable Money}

One reason that alternative monies are not perfect substitutes is that likely inflation rates for different monies can differ substantially. Expected inflation and variable unexpected inflation impose costs on holders of the money, and both expected inflation and variable unexpected inflation can generate revenue for an issuer of money. Expected inflation is costly to a holder of money because the real value of the money depreciates while it is being held. More variable unexpected inflation can generate costs because the environment is less predictable and the risk of engaging in various activities is higher. Expected inflation generates revenue directly to the issuer because 
printing more money creates higher inflation. More variable unexpected inflation can generate more revenue because the unexpected higher inflation can be supplied by printing more money, and the unexpected lower inflation raises the real quantity of cash balances demanded, which can be met by printing more money (Auernheimer 1974). The literature on time consistency and related issues, starting with Barro and Gordon (1983), shows that alternating periods of high inflation fueled by printing money and low inflation with money printed to provide the increased demand for money are difficult to sustain as an equilibrium. Even so, the incentive to produce such an outcome means that it can affect even a rational expectations equilibrium. Moreover, this incentive can affect the transition to a rational expectations equilibrium when agents are learning the preferences of the money issuer.

In models with learning, governments can acquire areputation for producing low, predictable inflation, but they also can acquire reputations for producing high inflation (Sargent 1999). Even if the choice of local currency is affected by legal tender laws, the choice of an international money is not affected directly by such laws. Hence, a money's reputation is all the more important for determining which money will be used as international money. As a result, it is not surprising that Cipolla (1967) places substantial weight on the stability of the money for determining what will be used as international money. It surely is important.

\subsection{International Trade}

Why might it also matter how much international trade is done by a country, as Cipolla (1967) suggests? At first glance, it is not obvious why this should matter at all. Even though Switzerland is a small country, people might well find Swiss francs to be the most useful currency and the emphasis above on inflation would suggest that as a real possibility. Even if a high-inflation 
country engages in a lot of trade, why would anyone want to use its money as an international medium of exchange?

Reflection on the functions of money, though, suggests that the quantity of trade will matter, and recent theoretical research provides support for this notion. The functions of money directly related to trade include its being a unit of account and a medium of exchange. Considering costs of changing prices - menu costs - suggests that reputation for low inflation is likely to be the important attribute for what currency is used as a unit of account because it affects the frequency of price changes. On the other hand, if the money used for a trade is different from the money used for posting the price, there is little obvious gain from posting the price in a stable currency since the actual transaction price in the unstable money has to be computed from the posted price in the stable money and the current exchange rate between the stable money and the unstable money. Menu costs interpreted narrowly would have to be very important in order to justify posting prices in a money different from the one used in the transaction. In domestic economies, prices commonly are posted in currencies other than the one used in trades only in the case of extraordinary inflations. Hence, it seems likely that the money used as an international unit of account will tend to be the dominant international medium of exchange.

Search-theoretic models of money show why the amount of international trade will matter for the choice of the money used as a medium of exchange. The indeterminacy of the choice of a particular fiat money as an international medium of exchange is very clear in the context of the search theories of money introduced by Kiyotaki and Wright (1989) and elaborated in a series of papers culminating in Trejos and Wright (1995). These search-theoretic models are particularly well suited to examining the general issue of international money because they do not impose the use of 
any particular money, or of money at all. Cash-in-advance models presuppose that a money must be used, and models with money in the utility function presuppose that a money is useful. Search theories of money allow for the endogenous choice of a money to solve the general problem of finding a double coincidence of wants.

The generality of allowing for an endogenous choice of money is bought at the price of the theoretical analysis being highly stylized. The choiceof a particular international money is examined in Matsuyama, Kiyotaki and Matsui (1993) and Trejos and Wright (1996). In these search-theoretic models of international money, countries are defined effectively by the probability that people will meet, and people can trade when they meet. People within a country have a probability of meeting another person from their country and a separate probability of meeting a foreigner. The probability of meeting a person within the country is assumed to be higher than the probability of meeting a foreigner. Trade is effected by an exchange of a money for a good when both sides find such a trade advantageous. This trade can be an exchange fordomestic or forei gn money. ${ }^{9}$ Matsuyama, Kiyotaki and Matsui (1993) show that the likelihood of using a foreign money is higher in equilibrium if the other country is larger and if the probability of meeting a foreigner is higher.

In short, a country that is larger and engages in more international trade is more likely to have its money used as an international money. This conclusion is derived holding constant other characteristics of the money, including the stability of the money.

These models have multiple steady-state equilibria for any sizes of economies and degrees of integration, even holding constant the reputation of the money for stability. While it is possible

${ }^{9}$ Barter will not occur because demand and production are structured to rule out a double coincidence of wants. 
at this level of generality just to say that there are multiple equilibria and leave it at that, it is neither desirable nor necessary to do so. Additional factors will determine the actual equilibrium observed. As Menger (1892, p. 250) summarizes the point, even the use of money domestically is the spontaneous outcome, the unpremeditated resultant, of particular, individual efforts of the members of a society, who have little by little worked their way [to a particular solution].

Actions that, in themselves, do not have any obvious implications for what money or monies will be international money can affect the actual money used.

Even if there are many possible equilibria, it is plausible that the likely inflation rates generated by a currency are of central importance among the variables affecting the actual equilibrium.

Other factors may matter too. On one level, there are curious things about the euro coins and notes. ${ }^{10}$ The euro coins differ by country of issue, with different backs on each. The notes are the same in all countries. These notes depict arches and other monuments, but the monuments are not real. The supposition apparently is that Germans would not be impressed by their currency having pictures of the Arc de Triomphe, and similarly the French would not be impressed by their currency having pictures of the Brandenburg Gate. Perhaps this will not matter; then again, it may turn out to matter.

${ }^{10}$ The euro was introduced with a substantial period to overcome some of the issues raised by Selgin (1994). 


\section{Conclusions}

A useful set of stylized facts emerge from our historical review of intemational monies spanning the fourth to the twentieth century. A sequence of international monies has existed historically, each occupying center stage sometimes for several centuries and eventually being replaced by the next. The only exception is the dollar, which is the current international money and, therefore, has not been replaced. These currencies have four key characteristics: they had high unitary value; they had relativelylow inflation rates for long time periods; they were issued by major economic and trading powers; and they became international monies by human action rather than by design.

Economic theory explains the roles of these factors. The size of a country matters because it affects the likelihood that someone in another country will trade with someone from that country and therefore the usefulness of a common money in trading. On the other hand, there is no necessary reason that people from two different countries will pick any particular money - especially a particular fiat money. Historically, this coordination problem was solved partlyby the relative values of metals, and therefore the usefulness of their denominations, and partly by the historical evolution of the choice of money. With fiat monies, the historical evolution of the use of any particular money assumes prime importance because the size of a monetary unit is relatively easier to change. Relative inflation rates affect the cost of holding different monies and therefore will affect the actual money used.

In recent centuries, international monies have been issued by countries with important financial markets to which foreigners have relatively free access. The relative importance of this factor is an important question for future research. 
What does this analysis suggest for the euro? The euro area is large enough in terms of trade to be a serious competitor to the dollar as an international money. Indeed, some European countries that are not part of the European System of Central Banks (ESCB) have adopted the euro. Whether the euro will replace the dollar in other geographic areas depends on two factors. The cost of holding euros relative to the dollar - largely determined by the relative inflation rate of the euro relative to the dollar - will be very important.

A more important factor for the euro than for other international monies, though, is the permanence of the European Central Bank (ECB) and ESCB itself. The European Common Market is an international organization and, while the single new money - the euro - has been created in ways that raise the cost of leaving the ESCB, it is not impossible for a country to quit the system. The ESCB is more nearly analogous to a currency union than to an international money in some respects, and currency unions' history has been one of formation and disintegration (Bordo and Jonung, 2000). If the European area evolves more nearly into a common government, then such disintegration becomes impossible short of civil war. Otherwise, it is an issue to be decided by participants in an individual country. In sum, the future of the euro itself is in doubt.

Conditional on the euro persisting for, say, fifty or a hundred years and the European Common Market not evolving into a single government, the euro may well supplant the dollar as international money if the euro's inflation rate is low relative to the dollar's inflation rate. If it does, then the euro will be the first international money that arose from planning rather than evolution. 


\section{References}

Ashton, T.S. 1955. An Economic History of England: The $18^{\text {th }}$ Century, New York: Barnes and Noble.

Auernheimer, Leonardo. 1974. The Honest Government's Guide to the Revenue from Money Creation, Journal of Political Economy 82, May-June: 598-606.

Barro, Robert J. and David B. Gordon. 1983. A Positive Theory of Monetary Policy in a Natural Rate Model, Journal of Political Economy 91, August: 589-610.

Bordo, Michael D. 1993. The Bretton Woods International Monetary System: A Historical Overview, in Michael D. Bordo and Barry Eichengreen (eds.) A Retrospective on the Bretton Woods System, Chicago: University of Chicago Press for the NBER, 3-104.

Bordo, Michael D. and Lars Jonung. 2000. Lessons for EMU from the History of Monetary Unions, London: Institute of Economic Affairs.

Chown, John F. 1994. The History of Money from AD 800, London: Routledge.

Cipolla, C.M. 1967. Money, Prices, and Civilization in the Mediterranean World, Fifth to Seventeenth Century, New York: Gordian Press.

Cohen, Benjamin J. 1971. The Future of Sterling as an International Currency. London, Macmillan; New York, St. Martin's Press.

Cohen, Benjamin J. 1998. The Geography of Money. Ithaca, N.Y.: Cornell University Press.

Darby, Michael, James R. Lothian and Arthur E. Gandolfi, Alan C. Stockman and Anna J. Schwartz. 1983. The International Transmission of Inflation. Chicago: University ofChicago Press for the NBER.

Dehing, Pit and Marjolein 't Hart. 1997. "Linking the Fortunes: Currency and Banking, 1550-1800," in Marjolein 't Hart, Joost Jonker, and Jan Luiten van Zanden(eds.) A financial history of the Netherlands, Cambridge and New York: Cambridge University Press, 37-63.

De Roover, Raymond. 1974. Business, Banking, and Economic Thought in Late Medieval and Early Modern Europe (edited by Julius Kirshner) Chicago : University of Chicago Press, 1974.

Einzig, Paul. 1970. The History of Foreign Exchange. 2nd ed. London: Macmillan.

Gilson, Etienne. 1991. The Spirit of Medieval Philosophy. Notre Dame, Ind.: University of Notre Dame Press. 
Hayek, Friedrich A. 1978. The Denationalization of Money: An Analysis of the Theory and Practice of Current Currencies. London: Institute of Economic Affairs.

Hayek, Friedrich A. 1967. The Result of Human Action not of Human Design, in Friedrich A. Hayek (ed.) Studies in Philosophy, Politics, Economics, and the History of Ideas. Chicago: University of Chicago Press.

Israel, Jonathan I. 1989. Dutch Primacy in World Trade. Oxford: Clarendon.

Israel, Jonathan I. 1995. The Dutch Republic: Its Rise, Greatness and Fall, 1477-1806. Oxford: Clarendon Press.

Jonker, Joost, The Alternative Road to Modernity: Banking and Currency, 1814-1914, in Marjolein 't Hart, Joost Jonker, and Jan Luiten van Zanden(eds.) A Financial History of the Netherlands, Cambridge and New York: Cambridge University Press, 1997, 94-123.

Kiyotaki, Nobuhiro and Randall Wright. 1989. On Money As A Medium of Exchange. Journal of Political Economy 97, August: 927-54.

Lopez, Robert S. 1951. The Dollar of the Middle Ages, Journal of Economic History 11, Summer: 209-234.

Lothian, J. R. 2002. Exchange Rates. Oxford Encyclopedia of Economic History, forthcoming.

Matsuyama, Kiminori; Nobuhiro Kiyotaki and Akihiko Matsui. 1993. Toward A Theory of International Currency. Review of Economic Studies 60, April: 283-307.

McCusker, John J. 1978. Money and Exchange in Europe and America, 1600-1775. A Handbook. Chapel Hill, N.C.: University of North Carolina Press for the Institute of Early American History and Culture.

Menger, Carl. 1892. On the Origins of Money, Economic Journal 2, June: 239-55.

Neal, Larry. 1990. The Rise of Financial Capitalism, Cambridge: Cambridge University Press.

Rolnick, Arthur J., François R. Velde and Warren E. Weber. 1996. The Debasement Puzzle: An Essay in Medieval Monetary History. Journal of Economic History 56, December: 789-808.

Sargent, Thomas J. 1999. The Conquest of American Inflation. Princeton: Princeton University Press.

Schumpeter, Joseph A. 1954. History of Economic Analysis. New York: Oxford University Press. 
Selgin, George. 1994. On Ensuring the Acceptability of a New Fiat Money. Journal of Money, Credit and Banking 26, November: 808-26.

Spufford, Peter. 1998. Money and its Use in Medieval Europe. Cambridge and New York: Cambridge University Press..

Spufford, Peter. 1984. Le rôle de la monnaie dans le révolution commericiale du xiïe siècle, in Etudes d'histoire monétaire / textes réunis par John Day, Lille:Presses universitaires de Lille.

Sussman, Nathan. 1993. Debasements, Royal Revenues, and Inflation in France During the Hundred Years' War, 1415-1422. Journal of Economic History 53, March: 44-70.

Tavlas, George S. 1998. The International Use of Currencies: The U.S. Dollar and the Euro, Finance \& Development 35, June: 46-49. Available at http://www.imf.org/external/pubs/ft/fandd/1998/06/tavlas.htm

Trejos, Alberto and Randall Wright. 1996. Search-Theoretic Models of International Currency. Federal Reserve Bank of St. Louis Review 78, May/June1996: 117-132.

Trejos, Alberto and Randall Wright. 1995. Search, Bargaining, Money, and Prices. Journal of Political Economy 103, February: 118-41.

Velde, François R., Warren E. Weber and Randall Wright. A Model of Commodity Money, with Applications to Gresham's Law and the Debasement Puzzle. Review of Economic Dynamics 2, January: 291-323. 
Table 10.1. Indices of exchange rates relative to the Florentine florin.

\begin{tabular}{lrrrrrr}
\hline & 1252 & 1300 & 1350 & 1400 & 1450 & 1500 \\
\hline Austria & 90 & 100 & 141 & 225 & 333 & 495 \\
Castile & & 100 & 431 & 1137.9 & 2586.2 & 6465.5 \\
Cologne & 37.5 & 100 & 336.3 & 630 & 915 & 1680 \\
England & 80 & 100 & 100 & 96 & 121.3 & 146.7 \\
Flanders & & 100 & 128.3 & 255.2 & 373.3 & 609.5 \\
France & 80 & 100 & 250 & 220 & 312.5 & 387.5 \\
Rome & 58.8 & 100 & 138.2 & 214.7 & 290.2 & 382.4 \\
Venice & 75 & 100 & 100 & 145.3 & 181.3 & 193.8 \\
\hline
\end{tabular}

Source: Lothian (2002 forthcoming), based on data from Spufford (1988). 